\title{
From the Co-Editors
}

Todd Pagano

Rochester Institute of Technology

National Technical Institute for the Deaf

tepnts@rit.edu

\author{
Sami Kahn \\ Princeton University \\ Council on Science and Technology \\ kahns@ohio.edu
}

Michele Hollingsworth Koomen

Gustavus Adolphus College

From the Editors...

Dear JSESD Readers and Supporters,

The Journal of Science Education for Students with Disabilities (JSESD) has been through several periods of transition, but has remained a venue for the dissemination of research and practice related to the education of students with disabilities in the science classroom and laboratory since 1998. Volumes \#1 through 11 were published in a print format. Starting with Volume \#12, the journal has been published online and Open Access.

Having JSESD in the Open Access format maximizes access for readers and authors and allows the journal to remain economically sustainable. The journal is currently hosted by bepress ${ }^{\mathrm{TM}}$ Digital Commons. The journal's management and production are led by the very talented group at Rochester Institute of Technology's Scholarly Publishing Studio led by Nicholas Paulus. This team has proved to be indispensable in the publication of JSESD.

We are very excited to announce that we have a new co-editor! Dr. Michele Hollingsworth Koomen has joined the editorial team and brings a wealth of experience to the journal. Some highlights of Michele's expertise and accomplishments include her roles as professor and now research professor at Gustavus Adolphus College in St. Peter, Minnesota where she taught science and math methods and content courses for undergraduate teacher candidates with a focus on inclusion and accessibility. Her publications can be found in journals such as Science Education, Journal of Research in Science Teaching, Cultural Studies in Science Education, American Biology Teacher, Science and Children and soon School Science and Mathematics. She was the lead editor of the edited book: 
Towards Inclusion of All Learners through Science Teacher Education, published in 2018 through Brill publication. She served for many years as the Chair of the Association of Science Teacher Education (ASTE) Inclusion Forum. Her research and practitioner knowledge in inclusive teaching and learning have been spotlighted in presentations and invited sessions at NSTA, ASTE, AERA, NARST and state and regional conferences for many years.

The journal enthusiastically seeks new manuscript submissions. We are especially interested in articles on science education for students with varying types of disabilities and at a full range of grade levels (K-12 and postsecondary). We are also eager to include articles that represent the full research-topractice continuum. While most manuscripts submitted to JSESD have historically focused on research, we have recently seen an increase in practitioner, or "Teaching Techniques" articles. We are delighted to see these articles, as they provide practical, ready-to-implement approaches for educators at all levels. To provide guidance for those wishing to submit a teaching techniques manuscript, we invited Dr. Jonte' C. Taylor, Associate Professor of Special Education at Penn State University, to write an article explaining the unique elements of such articles. We encourage you to read his article, entitled, "Publishing Successful Practitioner Manuscripts for the Journal of Science Education for Students with Disabilities" in this issue.

We are proud of the close relationship that $J S E S D$ has with its partner organization, Science Education for Students with Disabilities (SESD), which is an associated group of the National Science Teaching Association (NSTA). Each year, SESD holds a pre-conference on science and disability at NSTA's national conference. Due to COVID-19, the 2021 NSTA national conference has been cancelled. However, plans are currently underway for a virtual event. For further information, please contact Rachel Zimmerman Brachman, SESD Conference Coordinator, at: Rachel.ZimmermanBrachman@jpl.nasa.gov.

A few reminders:

- The journal resides online and freeof-charge.

- Manuscripts should be submitted online at http://scholarworks.rit.edu/jsesd/.

- There are currently no fees charged to authors for publication in JSESD. As an open access journal, articles are also free for anyone to read.

- JSESD uses a double-blind review of manuscripts.

One of the largest challenges to the journal currently is the solicitation of peerreviewers/referees for manuscripts. Please email us if you'd be willing to be considered for future reviewing assignments.

We know that there is a considerable amount of high-quality scholarship that is being conducted in the field of science education for students with disabilities. JSESD is proud to serve as a mechanism for the dissemination of such work. As always, we appreciate your support in maintaining $J S E S D$ as a quality peer-reviewed journal. 
Sincerely,

Todd Pagano, Sami Kahn, and

Michele Koomen

Todd Pagano, Ph.D.

Co-editor, JSESD

Rochester Institute of Technology/

National Technical Institute for the Deaf

Sami Kahn, J.D., Ph.D.

Co-editor, JSESD

Council on Science and Technology

Princeton University

Michele Hollingsworth Koomen, Ph.D.

Co-editor, JSESD

Gustavus Adolphus College

About the JSESD logo/cover:

Cathy Chou (Prof. of Imaging Arts \& Sciences at RIT/NTID) created the JSESD cover.

The background DNA image was strategically chosen to symbolize the interplay of JSESD's readership; that of experts in various fields of disabilities along with experts in the disciplines of science. The two intertwined sides of the double helix backbone represent this relationship. The rungs of the DNA structure represent the various age groups (K-Postsecondary) of students on which the journal focuses. 